Title: Ethnography amongst the British upper-middle classes: writing about or writing a gentry class?

Author: Daniel R. Smith

Institution: Anglia Ruskin University

Author Biography: Daniel R. Smith is Lecturer in Sociology at Anglia Ruskin University (Cambridge, UK). He gained his $\mathrm{PhD}$ from the University of Exeter. His thesis became a monograph published as Elites, Race and Nationhood: The Branded Gentry (Palgrave, 2016). He has written on social class, whiteness, brands and value, celebrity and the self as well as stand-up comedy. His research interests include British social class, especially the 'upperclass', identity, value and social and cultural theory.

Academic Level: MA * PhD * Early Career Researcher

Methods Used: Ethnography * Dialogism * Inductive Interviews * Participant Observation

Key Words: Ethnography * Class * Brands * Dialogism * Participant Observation *

Research Outputs: http://www.palgrave.com/gb/book/9781137509604

\title{
Learning Objectives:
}

- Appreciation of the centrality of writing and the literary nature of ethnographic writing

- Knowledge of how the ethnographic writing process engages with multiple texts in the discursive construction of its objects of analysis

- Knowledge of the major contributions of Bakhtin's concepts of chronotopes and his philosophy of dialogism for the writing of ethnographic texts

- Appreciation of how ethnography gives special insight into the novel and the déjá vú. 
Abstract: This case study is concerned with the writing of an ethnography about young upper middle class British people. Against the backdrop of a published ethnographic monograph, Elites, Race and Nationhood: The Branded Gentry (Smith, 2016), the case study explores how the empirical subject matter - an ethnography of a brand, Jack Wills, and their upper-middle class participants - gave rise to re-interpreting British social class through a bygone category: gentry. Ethnography is, simply, writing about culture. As such part of the ethnographic process is engaging in the production of social categories and concepts as much as rendering apparent the cultural universe under consideration. In this case study I outline how and why an archaic class category may be able to be utilised for its ability to shed new light on existing accounts of class and culture in British society. Taking into account that ethnography necessarily ends up as written texts, the case-study explores how ethnographic methods requires dialogue with texts, people and practices so as to fully elucidate the novel aspects of social life it captures. By so doing it brings to light new information about existing social problems. In this regard the literary construction of a 'gentry' out of historical context does not do violence to social reality, instead it shows how longstanding notions of belonging and class distinction become reimagined in relation to present social-economic arrangements.

\section{Introduction}

\section{$\underline{\text { Preamble }}$}

In January of 2016 I was invited to give a seminar paper on my book, Elites, Race and Nationhood: The Branded Gentry (2016), at the University of East Anglia. Immensely flattered that the research had been picked up by others, I effectively gave them a whole chapter from the research. It was an ethnographic account of a skiing trip which I had taken in pursuit of the lifestyle practices of upper-middle class young people, an event which was overseen and 
promoted by the clothing brand, Jack Wills. The brand, so called Outfitters to the Gentry, was my way into studying the culture and rituals of upper-middle class young people in Britain in the early $21^{\text {st }}$ century. I less was interested in how a clothing company drew upon the aesthetics and imagery of the British 'upper-class' for their marketing. Instead I was trying to understand the dynamics of upper-middle class privilege. The conclusion I came to was that instead of branding gentry, Jack Wills created a branded gentry, a set of social relations with attendant spatiotemporal realities, status relations, values and economic modalities which draw remarkable parallels with the landed gentry.

\section{$\underline{\text { Sociology, class and ethnographic analysis }}$}

Sociology, largely, has little concern with the historical importance of this anachronistic class, relegating it to a bygone era. Yet until the middle $19^{\text {th }}$ century the gentry remained the dominant class in British society. A class, that is, which forged not only British capitalist development but also our distinctive national aesthetic, our sacralisation of the countryside and its social hierarchies - our national love-affair with Jane Austen Arcadia - which is not only classed but racialized. Essentially, I wanted to argue that the power and significance of a branded gentry was one whereby longstanding ideals of belonging and racial-class privilege were being reimagined and redeployed as we enter the era of 'branded' capital, where wealth rests upon ownership of financial and equity capital (Piketty, 2014) and immaterial labour offers new forms of empowerment and dispossession (Hardt \& Negri, 2004).

Indeed having given this argument in relation to the ethnographic detail, an audience member asked: "So if I were to walk into Jack Wills in town and they had your book on the shelf, how would they match up? The story you're telling is in line with the image the brand wants to promote and have people think of them as..." Quite! What this question probed at was the fact that ethnographies, first, exist in dialogue with other competing narratives, voices and 
points of view. Second, he was observing that ethnographies in part engage in writing their objects of study into existence just as much as the social actions of those they observe enact their cultural universe.

In what follows I'm going to try and answer this question more fully than I did then. To do so I will, quite simply, outline how I engaged with the research process and explore some points which have bearing upon the philosophy of the ethnographic method. The first point is first and foremost they aim to provide a forceful description of the way of life and social activities of a particular culture. The second, and directly following the first, is that such descriptions provide space for elucidation upon theoretical questions (in this case, what do we mean by social class, culture and distinction at the upper-levels of the class hierarchy?) But the real value in this argument is that, hopefully, I can convince you that ethnography does in part write into existence its worlds but this is not, necessarily, to be thought of as doing harmful violence to social reality. For, in short, this is what the questioner was potentially accusing me of.

\section{$\underline{\text { Writing cultures and dialogism }}$}

To do this I will cover three main aspects of the researching and writing process (the two being, in essence, one and the same). The first is arriving at a sociological problem and its empirical territory. The second is turning this into an ethnography, a method which involves ingratiating and immersing oneself in a particular 'way of life' (which practically means 'hanging out' with people and not being asked to leave). It involves forging contacts and engaging in dialogue with 'others' so as to illustrate evidence in relation to an overarching theoretical, or simply conceptual, argument - a vision of the social world. The third is dialogism and ethnography. Dialogism, a term used to distil the ideas of Russian literary theorist/philosopher M. M. Bakhtin, refers to the epistemological stance which submits that 
human cultures never create absolutely: they are always in the process of making, being given new shape and always contingently being made to seem whole and finite (see Holquist, 2002). In practical terms, the dialogic ethnographer is one who engages in their fieldwork as a process of negotiated, mutual attempts at understanding between researchers and their participants. Crucially it points out how the conversations engaged in the writing of a sociological (or anthropological) 'text' is contingent and necessarily involves dubious claims to 'consummation' (to being complete and whole).

\section{The sociological problem}

\section{7: Pre-ethnography}

Some eight years prior to having completed the research, in effect that it has been written and published, I began my undergraduate degree in History \& Sociology at the University at Exeter. It was late 2007. This is where the first seeds of the ethnography took shape. In reality ethnographies don't really have a practical beginning, middle, end (instead they're made too seem like that).

It was Fresher's Week, in the student bar, The Ramm, then decorated in the style of a dilapidated barn serving pints of Carlsberg for a pre- 'credit crunch’ £1.10. In this packed pub I was asked by a fellow fresher a question I've only ever heard in British novels about university, by which I mean Oxbridge: "What school did you go to?” I don't think he was taller than me but he seemed it. Spotting the logo on his shirt - a pheasant wearing a top hat with walking cane, in shocking pink - I guessed at how this interaction would follow. Slightly uneasy, I said, "Oh, erm, Charters."

It was loud and mishearing, "Oh, Charterhouse" he replied, "Did you know Harry Fortescue?" 
“No, sorry, Charters. It's a comprehensive in Surrey." He walked away. With eight years hindsight I might not put this interaction down to his poshness being impatient with my plebeian origins (as I did at the time). It might not be another case of judging class as in, say, an Evelyn Waugh novel (although it did feel like that). I would instead like to suggest that such a simplistic reading doesn't do justice to the ethnographic story I wanted to tell. For I was no stranger to persons named Harry Fortescue. Despite Charters being a comprehensive, the Surrey/Berkshire upbringing I "enjoyed" offered a window onto the privileged existence of white, upper-middle persons. I could claim to being very marginally associated with it. The summer of 2007, prior to Exeter, had been spent holidaying on Hayling Island, messing about on my friend Ollie's boat with friends Tom, Alex, Olivia, Helen and Chole. Ours was not a world too far from those who attended Charterhouse and during our time spent with other Hayling Island summer residents - in their second homes - I'm sure there were some Old Carthusians among them. While we stayed only a week in Ollie's parents static caravan, their sailing club membership got us into the parties of the 'season' Islanders. It was, in unreflective adolescence, both normal that we be there but also a holiday, a time out of usual existence. Yet there was no sense of habitus, capitals or fields out of line when it came the mutual impasse in the Ramm bar. The shared sense of common trajectory amongst myself and the Harry Fortescue's is not the issue - Ollie and Alex went to Cambridge in '08, as they were the year below me, Helen in '09 (gap year...), Olivia to Central St. Martin's - but instead there is something else at work.

Here we are at the beginnings of ethnographic observations. To do an ethnography means noticing the strangeness of social interactions and their dynamics. With its origins as the central method of anthropology, the ethnographic method attempts to understand the lives of people who are, simply, 'different to you and I'. With my experience on Hayling Island, what was being noticed was how life trajectories may share similar flight paths but have 
radically different origins and slightly different experience of their destinations. These microinteractions in the summer prior to university provide insight into a sociological fact: the 1990s and early 2000s saw the entry of many 'non-traditional students' to Britain's universities, previously the haunt of Britain's highly intelligent and more often than not, socially privileged. In emic terms (ethnographic terms for 'native people say this'): posh kids. Ethnographic observations mean being aware of broad social trends and showing how they manifest themselves in the lived experience of those living through them. Show, don't tell.

\section{$\underline{\text { Sociology, social change and class identities }}$}

But this is not the beginning of The Great Gatsby with its discussion of gated island communities and old school ties. My ethnography referred to a sociological problem: how do upper-middle class modes and spaces of sociability maintain their coherence in a world which is increasingly open to not so much parvenus - for such a term is indicative of a much more rigid set of status distinctions - but a change in the criteria of entrance? That is, a world where social mobility and merit become increasingly the currency of entry into elite institutions (Khan, 2011). Simply it is, how upper-middle class privilege and exclusivity remains despite social changes which have sought to widen access to elite institutions.

One could elaborate upon this question to state that it involves tracing institutional changes in the university sector in the last twenty years but, moreover, it involves looking into a wider spatiotemporal remit than this. It comprises looking into processes of change within the economy and culture which bear upon class dynamics and tracing them empirically. For the lines of distinction which exist between Harry and I, and others who are likely to experience something similar, is not a case of classic economy and culture clashes - between economic capital not being translated into appropriate embodied cultural capital, etc. (Bourdieu, 1986) but rather longer and more nuanced forms of belonging in British culture and society. 
It is here where the concern with gentry, as both a conceptual and empirical object of analysis, presents itself. Gentry, I have suggested (2016:4-5; 25-30; 45-47), is a historically and culturally significant term in Britain's class nomenclature which, through collection of ethnographic material, may reveal itself to shed light upon a continuity and reformation around what 'class' and 'racial' forms of belonging consists of and involves in Britain today. What an ethnography aims to do, then, is immerse oneself in a cultural universe - with people, objects, texts (historical, commercial, sociological etc.) - in order to both build a picture of how a culture imagines itself to be, "for ethnology is first all psychology" (Lévi-Strauss, 1966:131). Then, by way of immersion, - both in the imagination and with real people 'in the field', demonstrate how particular cultures solve the problems they set themselves: how they maintain a sense of coherence between 'then and now'.

Or at least that is the theory of the method. Practically it is a much more hotchpotch process. In practice ethnographers (writers of culture) keep notebooks. The first lesson of ethnography, according to father of British social anthropology, Bronislaw Malinowski, is: 'write everything down'. Taking note of nearly every occurrence has the effect of (a) not letting you forget what you saw, heard or was told and (b) the value of hindsight, for observations forge themselves, retrospectively, into evidence of a sociological case.

\section{Ethnography against Bourdieuian sociology}

With that in mind, we can say that when it came to that slightly jarring interaction on my first week of university it is trivial both sociologically and personally. In the sociology of class and education, mostly influenced by Bourdieu, it's a common observation that merits in access does not translate to legitimate belonging. Ethnography is after the novel, not the cumulative. When it comes to ethnography, insight comes from shedding new light on existing facts of the ethnographic record. Indeed, it does not offer itself up to the autonomy and 
cumulative procedure of building "systems of hypotheses organized into coherent models capable of accounting for large sets of empirically observable phenomena" as Bourdieu (2013:9) suggests sociology ought to do. It seeks out that "literary logic ... between the singular and the common, the novel and the déjá $v u$ " that Bourdieu (2013:7-8) disparaged. Yet, I would suggest, the virtue of the 'literary logic' it offers is both familiar and strange insight into a culture that ethnographers strive to render apparent. One which connects what is new with that which has uncannily 'come before' (déjá vu). Bourdieu is certainly correct to suggest that there is a naivety, often a journalistic sensationalism to this literary logic. However, ethnographers have the virtue of avoiding this: they provide a nuanced account, as much as social life is itself lived nuancedly, into the peculiar ways which human cultures generate shared, meaningful ways of life. Practically, it is how these cultural forms are negotiated in situated contexts and across time-space, both personal and historical.

\section{Oxbridge in the 1960s: The Cambridge Manner}

In 1967 John Windsor wrote of "Oxbridge and Redbrick: the great divide.” Written at a time of educational reform, Windsor's largely observational material elucidates what he saw as the difference between the manners and disposition of the public school and grammar school entrants. It was clear that at that time the public-school Oxbridge entrant's social status was seen as their defining, and legitimate, claim to membership. Windsor observed that regardless of academic merit the predominance of status-based precedence of the public school entrant marked their ease and entitlement. For Windsor, this performance of legitimate membership was doubly articulated, it was conflated as both the institution and its socially prestigious entrants: "The 'Cambridge manner' is distinctly upper-class and distinctly public-school" (Windsor, 1967:61). The 'Cambridge manner' was defining both the university and those who embodied it. The 'Cambridge manner' was engaged in a process of hierarchical encompassment, a term used by anthropologists when observing relations of hierarchy (notably 
the work of Louis Dumount (1970) on the Indian caste-system). Ethnographically it is useful to look at relations of status and hierarchy as a series of encompassments, the Brahmin encompass the Kshatriyas as Queens do Jacks on playing cards and public-school Oxbridge students do grammar schools. The point is that cross-culturally one sees encompassment working by a logic which judges' hierarchical categories based upon a transcendent notion of what counts as culturally significant meanings. These transcendent ideals, extending back in time or arising from 'elsewhere' (Gods, spirits, ancestors), become unequally realised in certain members of a particular culture and are drawn upon to judge worth, where worth is the ability to stand for cultural ideals.

\section{From the Cambridge manner to the Jack Wills lifestyle}

What was new in 2007 compared to 1967 was that the terrain of membership had overturn the a priori claims of public-schooling, and performance of a 'Cambridge manner' as legitimate. The climate of higher-education was (and is) actively trying to promote a landscape of widening participation, which extends to social class as well as ethnic, and gender, inclusion and endorses meritocracy as the basis of membership. Indeed, this narrative cannot be separated from structural changes within the economy whereby service labour and professionalization has taken over from an industrial and skills economy. Previous ideals of membership are 'elitist', in the pejorative sense of the term, and to be rethought. But cultures don't move on as quickly as dominant political ideals.

In 2007, and throughout the time of the ethnography 'proper' (2010-2013), the observations and conservations I was having with both my participants and sociological texts was suggesting that 'the Cambridge manner', as Windsor termed it, was not so much disappearing but rather finding new and transformed cultural expression and institutionalisation. Ethnographic observations often become contemplations in the writings of 
the ethnographer (see Back, 1994:6): more and more the dynamics of my interactions with those deemed 'posh' - usually publically educated; usually speaking in RP; usually with confidence beyond mine or my immediate peers and so on - seemed to fit into the pages of Oxbridge novels. But, and here is the contemplation, they were occurring amongst people at provincial universities (Durham, Exeter, Bristol) and less from those I was speaking to at Oxbridge. So, what had happened? The observations show a pattern in culture, but one disrupted. The ethnographer probes further from this point.

Here is where the Jack Wills brand comes in. In the summer of 2007, on Hayling Island, Tilly - a good-looking blonde haired 19 year old - with a group of friends, later to be dubbed 'Seasonnaires' by Jack Wills - made a video of her and some friends on her sailing boat. She was a member of the same sailing club which Ollie was a member. But she, however, lived on island in the summer months and the Jack Wills brand found her depiction of it, through hers and friends video-footage, worthy of being placed on their website as promotional material for their clothing store. During my undergraduate time at Exeter I followed the gossip, reports both student press and national - on the brand with a strange fascination. Always I kept in mind Tilly and her boat footage when I thought of how she and her lifestyle was defined as being endorsed by Jack Wills, Outfitters to the Gentry and University Outfitters. Instead of talking about 'the Cambridge manner', as with Windsor in 1967, by 2007 what was being outlined was the 'Jack Wills lifestyle'; people and places were described as 'very Jack Wills'. There was a residue of the 'Cambridge manner' but it had in effect changed into a commercial and immaterial ideal associated with a brand-name. The transcendent ideals of belonging, once localised around public-schooling and Oxbridge, had expanded into the imaginary relationships people now had with immaterial 'brand-names' and their visual and aesthetic material.

\section{On chronotopes in ethnographies}


This is where the ethnography took shape. Given the narrative account I have outlined provided so far, it appears much more linear and rational a thought process. This is not the case. My knowledge of sociology and anthropology in 2007 was rudimentary, being a first year undergraduate, and by the time I was a PhD student in the autumn of $2010 \mathrm{I}$ had at best a vague idea of what the ethnography would be or even focus upon. But if I could in retrospect give you an idea of what I 'did' so as to give it more of a sense of coherence than it in reality had, I would say that what I was initially investigating was something ethnographers often drawn upon. This is chronotopes (literally, time-space), a concept derived from the work of Bakhtin (1981).

By the term, Bakhtin was invoking the way in which time-space is made to feel intrinsically connected in literary forms. This sense of time-space as unified in stories, Bakhtin argued, was due to a process of assimilation from the temporalities of the societies through which stories arise. How senses of time-space become conceptualised - that is, how they mean something and evidence cultural ideals, desires, values - is subject to a patchy process of crosscultural and trans-historical borrowing, sedimentation and re-articulation. We witness the power of chronotopes - ways of connecting time-space in narratives - in genres. The conventions, motifs, ideals, plot-devices and points, character-types in genres take on their full meaning and significance through the chronotope - time becomes, as Bakhtin says, "palpable and visible": events are knitted together and made meaningful as they are unified by intrinsic senses of connection (1981:250-251).

All this philosophical abstraction, however, does have a practical application. Ethnographies almost by definition need to outline the time-space in which they take place; they also need to give some account of how their units of analysis - systems of kinship, exchange, magic and ritual, etc. - were forged historically (be that through records, customary accounts, etc.); and they also need to, also, be written within some genre (see Rapport, 1994). 
With that in mind, there were three chronotopes at work in the ethnography of the young uppermiddle classes I conducted. The first was the origin and territories of the Jack Wills brand, where it came from and where it was spreading to. The second was that of the term 'gentry' and class categories more generally. The third was the time-space extension of the goods and services of the Jack Wills brand itself.

\section{Brands and class categories}

\section{$\underline{\text { Brand chronotopes }}$}

The 'time of the brand', its origins and scope, cannot be separated from the classed universe of the society in which it is embedded. While there is a great deal of theoretical literature related to this - (see Holt, 2004) - the simplest litmus test is how brands are spoken about and interpreted in the field of study. Before I had begun any practical fieldwork - forging contacts, selection of field sites, sourcing observations and conversations - I simply read anything I could find about the Jack Wills brand. From its official accounts to newspaper articles, scathing blog posts and adoring ones too, I found that the accounts all shared a common problem: they were all unable to properly define the identity of the brand, or more specifically the classed identity it embodied. It was often described as 'posh', or used the term 'Sloaney' taken from the 1980s books by Peter York and Ann Barr on upper-middle class lifestyles; if 'middle class' was used it was often with qualification. Ultimately 'Jack Wills' also became a way to name poshness, Sloanery or this elusive sense of 'middle-classness' with qualification. One could even say that part of the effort of writing about this brand was in effect a way to hold a conversation about what class, especially white, middle-classness, consists of or even really means in the here-and-now (c. 2007-2013 when I was researching).

While on the one hand I connected these changes to the transformation of the university sector as outlined above as well as the economy (i.e. the post-Fordist production of images and 
immaterial affects), on the other I was interested in how these class terms and their articulation had a history - one which is longer than c. 1982 and Britain's economic shift to a post-industrial society.

\section{Class chronotopes}

Crucially I was interested in the term 'gentry' used by the Jack Wills brand. Class nomenclature have their histories. In the ways they are used in social life - including academic texts - they sediment the relations, both material and ideal, around which inclusive criteria ('gentry') and exclusionary aspects (those 'not gentry') are articulated. While the term gentry has its origins and use in British society in the early modern period (and gets dropped from proper usage as Britain entered the industrial age), what extensive reading and engagement with historical texts on 'the gentry', and its meanings, demonstrated was that something of that original usage remained.

A gentry class derives from the French gentrice which effectively translates to 'high born' (Coss, 2003). While this does show some indication to what British people mean when they describe someone as posh, gentry in British culture has often been twinned with the prefix landed, indicating an economy and set of productive relations which accompany it (Thompson, 1993). It referred to landowners who would lease out their land to others and, through rents, live unproductively from the labour of others. Yet, more than this, it encapsulated a whole economy and culture of the countryside but also the country (nation) (Mieksins Wood, 1993). Finally it also encapsulated a class dynamic, something of a relation between classes which says something about the performance and practices of this 'higher born' class. Most importantly here there was a profound ambivalence; gentry was both ascribed by birth, blood and ancestry and achieved through virtue, character and professional social capital (Nicolson, 2011). 
Instead of treating gentry as a product of a past (and therefore dead and gone) socioeconomic formation, the aim of the ethnography became looking at how the economic, social, cultural and evaluative aspects of gentry were being reimagined and rearranged in the early $21^{\text {st }}$ century. Ultimately doing this makes us re-evaluate and appreciate what gentry is and was, i.e. connecting the novel with the déjá vú.

\section{Origin of the brand chronotope}

This came out most clearly in the origin story of the Jack Wills brand. Beginning in Salcombe in Devon c. 1999 - a prominent, expensive holidaying haunt of second home owning upper-middle class white people (not dissimilar to Hayling Island) - the CEO, Peter Williams, imagined a brand which would encapsulate those holidays: booze and boats on the British coast, the university lifestyle of long summer holidays, the hubris of this age group as well as their sexual freedom; etc. etc. How he did this, however, was telling: he named the brand after his grandfather, or that is how the story goes, John Williams born c.1930 became Jack Wills (as old English posh naming customs dictate that John's become Jack (e.g. Sir John Falstaff in Shakespeare) and Williams become Wills (e.g. like Prince William). In the monograph the origin story is recounted in full and shown to follow - in the sources gathered (from Peter Williams himself, to secondary reports and conversations with former JW employees) - the exact same origin story of Jay Gatsby in Fitzgerald's The Great Gatsby (1993) (Smith, 2016:48ff). It was a 'gentry' origin story; its generic conventions utilised longstanding ideals around aspiration, privilege and inclusions/exclusion in upper-class circles.

Furthermore, the brand was described often as aspirational but with a series of persons who would be able to embody this aspiration to others. For instance, Tilly on her boat would, thereby, become by way of being named and captured by the Jack Wills brand the embodied form of aspiration which others would aspire to. While gentry in its historical sense has lost a 
lot of its meaning, what the process of interpretation between past and new meanings engaged with was how a vision of culture was being outlined. The term gentry gave both purchase to how identities and practices were on the one hand being classed, one which drew upon historical resources, and on the other hand how the ethnography might engage with how brands institutionalise processes which extend existing class dynamics.

\section{Gifts and patronage}

\section{Sociology of the gift}

When it came to the immersion within the field, the initial work on reading and interpreting gentry in British culture and history paved the way to looking into how gentry manifested itself within social relations and practices. The crucial observation which I focused upon was the dynamics of aspiration and ascription which gentry ambivalently encapsulated. In the field, this manifested itself in the dynamics by which branded goods were distributed. In the case of people such as Tilly, their favour and practices - of supplying a boat and the enjoyment of it - was supplemented by way of free goods from the brand, from restricted items which were given away at special events to clothing from the store which was given freely on return for favours. Effectively the ethnography was a process of tracing these exchanges, of favours for free goods and so on, to tease out their sociological consequences. The central finding was that by way of gifts the Jack Wills brand was institutionalising an economy of patronage which effectively hierarchized the relations people have with brands and their immaterial, affective economies (Hardt \& Negri, 2004). While you and I may 'buy’ our Jack Wills good, gazing at the persons on British beaches or skiing trips which line their store walls, the regimes of gifts and capturing this on film literally outfits a gentry whose life, its temporalities and social relations as well as practices, define the central criteria of which 'gentry' - a classed and racialized form of belonging - in Britain consists of. 
To do immersion isn't easy. In classic anthropological accounts countless stories abound about how 'informants' are difficult, hard to access, don't tell you what you want, tell you direct lies or don't co-operate. Indeed, the practicalities of entering in somewhere where there is no real, legitimate reason for you to be there is the problem encountered by all those who call themselves ethnographers. I certainly found this and while every effort was made to ingratiate - offering kindnesses, reading the social situation, assurances to your participants, etc. - feeling alien never went away. Gaining entrance requires trust; a gatekeeper who gives you the okay and bridges the gap between strangers. This was crucial in my research, for without one particular gatekeeper the research would never have begun. The practical point was that he was able to not only assure others but also assure me as well. Despite this, the alien feeling I had was never muted. This feeling alien is something which I read to do with class positioning. It informed not only my experience of the lifeworld, it confirmed itself in ethnographic conversations - talk about 'this world'.

\section{Ambivalent inclusion and exclusions 'in the field'}

The dominant motif in all interviews as well as observation 'in the field' was contested claims to inclusion or exclusion 'in that world', or 'the Jack Wills lifestyle'. These discussions were underlined by the affective criteria which circulated around as well as was institutionalised by the brand. In short, the Jack Wills brand had become a novel way to 'talk about' - contest, negotiate and claim membership to - a longstanding notion of class distinction in British society. While localised around a small-scale study of young, upper-middle class people involved with a global brand, the observations themselves furnish sociology with a way of looking into the continuities in the contested histories which inform, and re-inform, class distinction in Britain. Indeed, the sociological conclusion is that when it comes to looking into class categories, the production of classes and the relations which form between them is indeed the result of economic processes. Class is what happens to people as they become engaged in 
the ensemble of social relations which economic processes put in place. But moreover, when focusing ethnographically on how old class categories become re-institutionalised it requires detailed observation of how this drama plays out. Gentry need not be relegated to the socialeconomic regime for agrarian production, of landowner and tenants, but instead be shown to be a way of seeing how old meanings associated with a gentry class - their manner, their practices, values and exclusionary criteria - become evidenced in situated cases in the present.

How does ethnography furnish us with such claims? Ethnography relies upon observations and their re-articulation in written texts. The point is, class cannot be directly observed empirically. You can observe relations of power, but not class relations. What ethnographers can do is observe relations between people and how the shared set of assumptions and meanings they attribute to these relations and practices shape the realities in which they live. To make claims about class is in the ethnographers writing of it. When you conduct an ethnography, then, at each stage of the interpretation you are making judgements which are not true in the scientific sense (of empirically observable phenomena) but literary truths: they help you tell the story.

\section{$\underline{\text { Sociologies of class critique }}$}

Ethnography is especially placed for looking into claims of belonging and their negotiation. In short, how people deal with the social reality they are part of. The ethnographic material sourced in my case was a way of looking a social class as not a series of relational categories which are the product of histories manifested in bodies - which is effectively the Bourdieu inspired approach. Instead it was a concerned with looking at how individuals conceived of their relational classed experiences as claims to worth and the justification criteria which accompanied these through brand consumption. It is discernible that those who received gifts drew upon differing criteria of worth to those who purchased their branded items. Indeed, 
the language of entitlement and what Windsor called 'the Cambridge manner' become repositioned in the language of lifestyle - how one receives and judges others for the Jack Wills clothes. Sociologically, the hierarchies of social class, aspirations and privilege, entitlement and ressentiment, remain and become redeployed around novel terrain.

\section{Conclusion: dialogism and ethnography}

So when it comes to 'writing gentry', the point I want to end on is something which has bearing upon the practicalities of ethnographic writing as well as the practice of immersive fieldwork. The end point of all ethnographies, and all sociological work, is in sociological texts (be they peer-reviewed journal articles or case-studies to book chapters or monographs). As such the practical job of the ethnographer is to tell a story, one which captures the lived experience of participants and one which engages with the production of literary texts. As Bakhtin scholar Michael Holquist (2003:109) observed, both art and life - or ethnographic texts and the ethnography itself - are part of the same set of phenomena, "the heteroglossia of words, values, and actions whose interaction makes dialogue the fundamental category of dialogism." In this respect, the engagement with literary texts, such as The Great Gatsby, or historical sources, to the experiences I captured on skiing trips in 2012, refers to assimilating material that tries to say something about the nature of British social class. Indeed, the underlying ontology it promotes is one which says that the literary universe of an ethnography has a correlation to the meaningful life of the 'real', historical society under observation. It does so because the literary universe painted would be unintelligible if this wasn't the case. By

writing gentry into existence, the ethnographer aims to demonstrate the nuanced cases of distinction and continued inequalities which class names through narrative means.

\section{Discussion Questions:}


1. How does dialogism provide ethnographers with a critical tool for forging their categories of analysis?

2. Why does scientific sociology criticise ethnography's 'literary logic'?

3. How does ethnographic writing use the concept of chronotopes to provide its central aim of rendering apparent the lifeworld it investigates?

4. Does ethnography limit itself to capturing only the micro-dynamics of social life?

\section{Further Reading:}

While a lot of good ethnography 'textbooks' exist, if you want to conduct an ethnography you should read existing ethnographies. Here are some which all have that 'literary logic' discussed above:

Graeber, David (2007), Lost People: Magic and the legacy of slavery in Madagascar (Bloomington, IN: Indiana University Press)

Holbraad, Martin (2012) Truth in Motion: The recursive anthropology of Cuban Divination, (Chicago: University of Chicago Press)

King, Anthony (2004), The European Ritual: Football in the New Europe (Farnham: Ashgate)

Parry, Jonathan (1994) Death in Banaras, (Cambridge: Cambridge University Press)

Wacquant, Loic (2004), Body \& Soul: Notebooks of an apprentice boxer, (Oxford: University of Oxford Press)

\section{References:}

Back, Les (1996), New ethnicities and urban culture: Racisms and multiculture in young lives, (London: Routledge)

Bakhtin, Mikhail (1981), The Dialogic Imagination, (Austin, TX: University of Texas Press) 
Bourdieu, Pierre (2013) 'In praise of sociology: acceptance speech for the Gold Medal of the CNRS', Sociology, 41(1):7-14.

Bourdieu, Pierre (1986), Distinction: a social critique of judgement and taste, (London: Routledge)

Coss, Peter R. (2003), The origins of the English gentry, (Cambridge: Cambridge University Press)

Dumont, Louis (1970), Homo hierarchicus: the caste system and its implications, (London: Weidenfeld \& Nicolson)

Fitzgerald, Scott F. (1993), The Great Gatsby, (Hertfordshire: Wordsworth Edition, LTD)

Hardt, Michael \& Negri, Antonio (2004), Multitude: War and democracy in the age of Empire, (New York: Penguin)

Holt, Douglas B. (2004), How brands become icons: the principals of cultural branding (Harvard, Mass.: Harvard Business School Press)

Holquist, Michael (1990), Dialogism: Bakhtin and his world, (London: Routledge)

Khan, Shamus (2011), Privilege: the making of an adolescent elite at St. Paul's School, (Princeton: Princeton University Press)

Lévi-Strauss, Claude (1966), The Savage Mind, (Chicago: University of Chicago Press)

Mieksins Wood, Ellen (1993), The Pristine Culture of Capitalism, (London: Verso)

Nicolson, Adam (2011), The Gentry: Stories of the English,(London: Harper Press)

Piketty, Thomas (2014) Capital in the twenty first century, (Cambridge, Mass: Harvard University Press) 
Rapport, Nigel (1994) The Prose and the Passion: Anthropology, Literature and the writing of E. M. Forster (Manchester: University of Manchester Press)

Smith, Daniel R. (2016), Elites, Race and Nationhood: The Branded Gentry (Basingstoke: Palgrave)

Thompson, E. P. (1993), 'The Patrician's and the Plebs' in Customs in Common: Studies in traditional popular culture, (New York: The Free Press)

Windsor, John (1967), 'Oxbridge versus Redbricks' in Mabey, Richard (ed.), Class: A symposium, (London: Bond) 